\title{
The impact of diversity and educational backgrounds of executive boards on Indonesian bank performance
}

\author{
Arisma S. Putri ${ }^{1}$, Eka Mandala ${ }^{2 *}$, M. Farhan H. Harahap ${ }^{3}$, Reyhan S. Adinur ${ }^{4}$, Sasi \\ W. Ahad ${ }^{5}$, Dewi Hanggraeni ${ }^{6}$ \\ 1,2,3,4,5,6 Faculty of Economics and Business, Universitas Indonesia \\ *Corresponding Author: ekamandala20@gmail.com
}

\begin{abstract}
This study identifies and analyzes the relationship between the diversity of the board of directors and the president director's educational background on the bank's financial performance. Based on 38 samples of Indonesian banks that have been listed on the Indonesia Stock Exchange. This study examines the static and dynamic relationship between the framework, which controls for the specific effects of each of the factors being tested. The results of this study indicate a significant influence and direction of negative correlation between gender diversity and citizenship diversity on bank financial performance. This study also shows a significant influence and direction of a positive correlation between the president director with an economic or business education background on the bank's financial performance. This study also discusses several managerial implications for banking companies and recommendations for the government in relation to the regulation of the board of directors of banks in Indonesia.
\end{abstract}

Keywords: Bank Performance; Diversity; Board of Directors; Director's Education

\section{INTRODUCTION}

Corporate governance in the current global economic era is an essential part of managing financial institutions. This has also led to the failure of many financial institutions in the face of the global financial crisis, which can be attributed to the poor performance of corporate governance. Therefore, world governments are currently very concerned about the importance of governance of financial service providers, especially banks (Garcia-Meca et al., 2015). The board of directors is one of the key parts of corporate governance. Therefore the composition of the board must be responsive to the basic functions assigned to it, namely supervising and monitoring the company, avoiding opportunistic behavior as the executive, and providing advice and making decisions on complex situations (García Martín \& Herrero, 2018). Previous studies also consider that board diversity is an essential component that determines the characteristics of the board in making financial and investment decisions (Veltrop et al., 2015). King et al. (2016) added 
that educational background is also a fundamental asset that is considered in the appointment of a new President Director by a Bank or other financial institution.

In the concept of a board of director diversity, it is stated that the composition of the board of directors should reflect the community structure and represent differences in gender, ethnicity, and professional background (Pechersky, 2016). Factors such as age, gender, tenure, and field specialization are included in demographic factors related to values and perceptions and a person's cognitive ability to make decisions (Bulog, 2016). The more complex the strategic decisions that must be made in corporate governance management, the more critical the characteristics and background of the board of directors as decision-makers (Montiel Campos et al., 2015). These demographic characteristics contribute to the diversity of the board of directors (Tarus \& Aime, 2014).

The appointment of women in the composition of the board of directors of a company creates different perspectives in discussing board members' opinions (Goyal et al., 2019). Previous studies regarding the involvement of women as members of the board of directors produced mixed findings (Ionascu et al., 2018). For example, research (Wang, 2020) and (Ionascu et al., 2018) found a positive correlation and a significant effect on the involvement of women on the board of directors. Meanwhile, research (Post \& Byron, 2015) failed to find a positive and significant correlation to company performance for the involvement of women on the board of directors. (Adam \& Ferreira, 2009) also did not find a positive correlation and a significant influence on the involvement of women as members of the board of directors on company performance in the United States. Different findings may be due to differences in organizational structure, applicable regulations, and regulations in each country (Endrawati, 2017).

The existence of differences in ethnic representation on a board of directors can improve company performance (Sarhan et al., 2019). This occurs primarily due to national differences among members, providing new opinions, various professional experiences, and diverse perspectives to enrich knowledge and alternatives in solving complex problems (Saputra, 2019). Rahma \& Aldi's (2020) research results reveal that there are foreign members of the board of directors, indicating that globalization and information exchange globally and indirectly can convince foreign investors that the company has been managed professionally.

The director's educational background factor is often used as a reference for research on its effect on company performance. In the research of (Adnan. et al., 2016), it was found that the diversity of educational backgrounds in the form of various degrees, especially $\mathrm{Ph} . \mathrm{D}$. and non-PhD, has a positive relationship to company performance. On the other hand, (Mahadeo et al., 2012) found a negative relationship between the diversity of educational backgrounds and company performance.

The different results from previous studies regarding the effect of diversity in the board of directors on company performance increasingly attracted the desire of the research team to conduct a similar study. Using 38 banks in Indonesia have been listed on the Indonesia Stock Exchange from 2015-2019 as samples of the study. This study contains a discussion of developing hypotheses, then methods, data and analysis, and results, and ends with a discussion and research conclusions. 


\section{HYPOTHESIS DEVELOPMENT}

\section{President Director Education}

One of the essential roles of the company board is to select the president director (Chief Executive Officer or CEO) with good abilities (Elsharkawy et al., 2018). A director's ability to lead can be seen from two perspectives: observable characteristics and unobservable characteristics (Elsharkawy et al., 2018). Observable characteristics include work experience, career reputation, and education. Meanwhile, the unobservable characteristics include but are not limited to leadership abilities, the ability to gain trust and build a team. Measuring non-quantifiable characteristics can be a big challenge (Falato et al., 2015).

One of the characteristics that can be observed is educational background. Educational background has an essential role in selecting leaders. Papadimitri et al. (2020), in their research, found that companies whose crucial members of the board of directors have a higher level of education tend to receive higher credit ratings. Falato et al. (2015) also found evidence that company leaders with high educational qualifications positively impact company performance.

On the other hand, some researchers doubt the influence of the educational background of corporate leaders on the performance of the company itself. In their study, Gottesman \& Morey (2010) did not find a relationship between company performance and the educational background of their leaders. Even a company leader without a college degree can score more benefits than those with a degree (Jalbert et al., 2011).

In a banking context, (King et al., 2016) found that a bank-led by someone with an MBA (Master's in Business Administration) was likely to achieve a higher profitability value than a bank-led by someone without an MBA. Whereas in the context of risk, company leaders with an MBA will make more risky and innovative choices to achieve superior performance (Elsharkawy et al., 2018). This difference of opinion is a trigger to test whether the educational background of the president director has an impact on the performance of banks listed on the Indonesia Stock Exchange. Based on the discussion above, the following hypothesis can be formulated:

$\mathrm{H}_{1}$ : The president director's educational background has no impact on bank performance

\section{Diversity of the Board of Directors}

There are various dimensions of diversity that may affect company performance. Examples are gender diversity, education level, nationality, beliefs, and disabilities. Moreover, This study focuses on two types of diversity. The first diversity is gender diversity. The second diversity is the diversity of citizenship.

\section{Gender Diversity}

There are two views regarding the presence of female representatives on the board of directors of companies: ethical and financial (Campbell \& Mínguez-Vera, 2008). From an ethical point of view, the exclusion of women on the board of directors is considered immoral. Therefore, to create an equal situation between men and women, companies are required to increase the representation of women (Geiger \& Marlin, 2012). The presence of women on the board of directors can also bring different views in board meetings (Upadhyay \& Zeng, 2014). 
Meanwhile, some researchers argue that increased performance can be achieved from a financial perspective by increasing diversity. Based on the research of (Reguera-Alvarado et al., 2017), the existence of gender diversity, which is influenced by the gender composition in the company's board of directors (the higher the percentage of diversity), has a positive effect on improving the company's financial performance.

Astuti (2017) has conducted similar research on board of directors' gender diversity on company performance. The study results reveal that the proportion of female boards of directors does not affect firm value. Departing from this research, we would like to examine the effect of gender proportions on the board of directors on the company's financial performance using a sample of banks listed on the Indonesia Stock Exchange. Based on the discussion above, the following hypothesis can be formulated:

$\mathrm{H}_{2}$ : Gender diversity has no impact on bank performance

\section{Diversity of Citizenship}

As globalization, boundaries between countries are becoming more faded. The flow of information on strategic and corporate governance across countries has become more accessible (Petricevic \& Teece, 2019). This reduced limitation has resulted in the emergence of a new topic in research on the effects of diversity, namely on differences in nationality.

The diversity of citizenship can be a positive or negative thing for a company. Mazzotta et al. (2017) found a significant positive relationship between the presence of directors of foreign nationality and Tobin's Q. The same thing happened in Korea, using 457 companies as samples (Estélyi \& Nisar, 2016) found that boards with multiple nationalities positively and is significantly related to the heterogeneity of shareholders and company operations in international markets.

Several researchers found different research results on this matter. Research by (Elsharkawy et al.,2018) highlighted that boards of directors who have foreign nationals might experience domestic barriers such as awareness of industry regulations or overall job performance, making them less likely to affect the decision-making process positively. Frijns et al. (2016) also found that the board's diversity negatively affects company performance. Therefore, this study examines how the nationality of members of the board of directors affects banks' performance on the Indonesia Stock Exchange. Based on the discussion above, the following hypothesis can be formulated:

$\mathrm{H}_{3}$ : Diversity of citizenship has no impact on bank performance

\section{METHOD, DATA, AND ANALYSIS}

This study uses panel data consisting of 190 observations. Data is taken from 38 public banks listed on the Indonesia Stock Exchange (IDX). The data collection method uses secondary data obtained from DataStream and company annual reports using a nonprobability sampling technique with purposive sampling type. It determines based on the availability of data from 2015 to 2019. The company's annual report provides data on the financial measures needed (assets, equity, etc.) and diversity in the composition of the board of directors (number of female directors, number of non-Indonesian citizens, board of directors' educational background).

There are three independent variables and two control variables that affect the dependent variable or BPKF, representing bank performance measured by TQ, NIM, 
ROAA, and ROAE. For the independent variable, GEN which means the gender diversity variable, namely the proportion of women on the board of directors, NAT represents the nationality diversity variable in the board of directors. And EDU, which is a business education background. The control variable consists of bank size defined by the LnTA and ETA variables.

This study uses a simple linear regression model (OLS) and panel data regression to see whether there is an effect of the composition of the board of directors on the performance of the company. The equation for models 1 to model 4 uses the dependent variable to measure bank performance (BKPF) with Tobin's Q (TQ), Net Interest Margin (NIM), Return on Average Asset (ROAA), and Return on Average Equity (ROAE). The model compiled in this study is as follows in equation (1).

$$
B K P F=\alpha+\beta \cdot G E N_{i t}+\beta \cdot N A T_{i t}+\beta \cdot E D U_{i t}+\beta \cdot C_{C O T}\left(\operatorname{LnTA}_{i t}+E T A_{i t}\right)+\beta \cdot \varepsilon_{i t}
$$

Table 1. List of Variables

\begin{tabular}{|c|c|c|c|}
\hline Variable & Proxy & Symbol & Measurement \\
\hline \multirow{4}{*}{$\begin{array}{l}\text { Dependent } \\
\text { Variable }\end{array}$} & \multirow{2}{*}{ Tobin's Q } & \multirow{2}{*}{ TQ } & Market Capitalization + Total Liabilities \\
\hline & & & $\begin{array}{c}\text { Total Assets } \\
\end{array}$ \\
\hline & \multirow{2}{*}{ Net Interest Margin } & \multirow{2}{*}{ NIM } & Interest Revenue - Interest Expenses \\
\hline & & & Average Earning Assets \\
\hline \multirow{6}{*}{$\begin{array}{c}\text { Bank } \\
\text { Performance } \\
\text { (BKPF) }\end{array}$} & \multirow{3}{*}{$\begin{array}{l}\text { Return on Average } \\
\text { Asset }\end{array}$} & \multirow{3}{*}{ ROAA } & \\
\hline & & & Net Income \\
\hline & & & $\overline{\text { Average Total Assets }}$ \\
\hline & \multirow{2}{*}{$\begin{array}{c}\text { Return on Average } \\
\text { Equity }\end{array}$} & \multirow{2}{*}{ ROAE } & Net Income \\
\hline & & & $\overline{\text { Average Total Equity }}$ \\
\hline & Gender Diversity & GEN & Proportion of women in the board of directors \\
\hline \multicolumn{4}{|l|}{ Independent } \\
\hline Variable & Diversity of citizenship & NAT & $\begin{array}{c}\text { Proportion of foreign nationals on the board of } \\
\text { directors }\end{array}$ \\
\hline \multirow{2}{*}{$\begin{array}{l}\text { Diversity of } \\
\text { the Board of } \\
\text { Directors }\end{array}$} & & & \\
\hline & $\begin{array}{l}\text { Educational } \\
\text { Background }\end{array}$ & EDU & $\begin{array}{c}\text { The dummy variable, } 1 \text { means having a business } \\
\text { education background, } 0 \text { having no business } \\
\text { education background }\end{array}$ \\
\hline \multirow{3}{*}{$\begin{array}{l}\text { Control } \\
\text { Variable } \\
(\mathrm{COT})\end{array}$} & & LnTA & Ln from Total Assets \\
\hline & Bank Size & & \\
\hline & & ETA & Percentage of Total Equity to Total Assets \\
\hline
\end{tabular}




\section{4. $\quad$ RESULTS}

Table 2 below contains a descriptive analysis of this study. Tobin's Q (TQ) will be the ratio to measure bank performance. The average TQ ratio obtained was 1.0917. This value is greater than the findings in the previous study (Elsharkawy et al., 2018), which received an average TQ ratio of 0.598 . In contrast, the average ROAA, ROAE, and NIM obtained were much lower than the three from previous studies. The ROAA, ROAE, and NIM values obtained were $0.01,0.042,0.0507$.

Table 2. Statistical Description

\begin{tabular}{lccccc}
\hline \multicolumn{1}{c}{ Variable } & Max & Min & Mean & Std. Dev. & N \\
\hline TQ & 3,315 & 0,8562 & 1,0917 & 0,2298 & 190 \\
ROAA & 0,05 & $-0,12$ & 0,01 & 0,02 & 190 \\
ROAE & 0,2868 & $-1,3253$ & 0,042 & 0,154 & 190 \\
NIM & 0,12 & 0,0107 & 0,0507 & 0,0185 & 190 \\
\hline & 0,75 & Explanatory Variables & & \\
\hline GEN & 0,5 & 0 & 0,2029 & 0,1852 & 190 \\
NAT & 1 & 0 & 0,0706 & 0,1237 & 190 \\
EDU & 1,1454 & 0,9105 & 0,2854 & 190 \\
\hline & 0,5156 & 0,0138 & 0,1528 & 0,0532 & 190 \\
\hline LnTA & Control Variable & & \\
ETA & & 0,2061 & 0,1132 & 0,1747 & 152 \\
\hline
\end{tabular}

Note: TQ: Tobin's Q, ROAA: Return on Average Asset, ROAE: Return on Average Equity, NIM: Net Interest Margin, GEN: Gender diversity, NAT: Citizenship diversity, EDU: Educational background, LnTA: Ln of Total Assets, ETA: Percentage of Total Equity to Total Asset.

Table 3. Matrix Cross Correlation

\begin{tabular}{|c|c|c|c|c|c|c|c|c|c|}
\hline $\begin{array}{c}\text { Correlation } \\
\text { Matrix }\end{array}$ & GEN & NAT & EDU & SIZE & ETA & TQ & NIM & ROAA & ROAE \\
\hline GEN & 1,000000 & & - & - & - & - & - & - & - \\
\hline NAT & 0,118889 & 1,000000 & - & - & - & - & - & - & - \\
\hline EDU & 0,025304 & $-0,007471$ & 1,000000 & - & - & - & - & - & - \\
\hline LnTA & $-0,010762$ & 0,056060 & $-0,034704$ & 1,000000 & - & - & - & - & - \\
\hline ETA & 0,054414 & 0,088431 & 0,185335 & 0,257086 & 1,000000 & - & - & - & - \\
\hline $\mathrm{TQ}$ & $-0,035554$ & $-0,111643$ & $-0,012249$ & 0,348555 & 0,432885 & 1,000000 & - & - & - \\
\hline NIM & 0,019479 & 0,038550 & $-0,068543$ & 0,032754 & 0,210898 & $-0,008879$ & 1,000000 & - & - \\
\hline LnTA & $-0,050689$ & 0,117290 & 0,014396 & 0,109310 & $-0,153292$ & $-0,388588$ & 0,442217 & 1,000000 & - \\
\hline ETA & $-0,001305$ & 0,072277 & $-0,001802$ & 0,270713 & $-0,068016$ & $-0,205678$ & 0,437267 & 0,924279 & 1,000000 \\
\hline
\end{tabular}

Note: TQ: Tobin's Q, ROAA: Return on Average Asset, ROAE: Return on Average Equity, NIM: Net Interest Margin, GEN: Gender diversity, NAT: Citizenship diversity, EDU: Educational background, LnTA: Ln of Total Assets, ETA: Percentage of Total Equity to Total Asset. 
Table 3 is a cross-correlation matrix that shows the correlation between the dependent variable and the independent variable. From the table, it can be seen that gender diversity as measured by the proportion of women on the board of directors has a negative correlation with company size as measured by total assets (SIZE), firm performance (TQ), INTA, and ETA. As for the nationality variable, the correlation between foreign citizenship in the board of directors has an inverse relationship to educational background and company performance. This can be seen from the negative value on both the EDU and TQ variables. The education variable of the $\mathrm{CEO}$ who must have an educational background in business (EDU) has a negative relationship to company size (LnTA), NIM, and ETA.

Furthermore, table 4 shows the estimation results using the pooled OLS method. Of the four models, there is no significant effect of the explanatory variables used, namely gender, nationality, and the level of education of the director. Several control variables are used to analyze better the estimation results, such as company size (INTA) and asset-toequity ratio (ETA). As a result, firm size has a significant positive effect on the TQ, NIM, and ROAE models. In contrast, the asset-to-equity ratio has a significant impact only on the TQ and NIM models.

Table 4. Estimation Results Using Pooled OLS

\begin{tabular}{ccccc}
\hline Variable & Model 1 (TQ) & Model 2 (NIM) & Model 3 (ROAA) & Model 4 (ROAE) \\
\hline Konstanta & 0,883928 & 0,045401 & 0,006421 & $-0,007700$ \\
GEN & $-0,007313(0,9402)$ & $0,000373(0,9649)$ & $0,000361(0,9703)$ & $0,069747(0,3282)$ \\
NAT & $-0,310952(0,0336)$ & $0,00273(0,8274)$ & $0,02285(0,1153)$ & $0,081582(0,4424)$ \\
EDU & $-0,078731(0,2779)$ & $-0,008524(0,1733)$ & $0,002428(0,7361)$ & $-0,007168(0,8922)$ \\
LnTA & 0,442396 & $-0,004495(0,6980)$ & $0,022889(0,0863)^{*}$ & $0,279713(0,0047)^{* * *}$ \\
& $(0,0011)^{* * *}$ & 0,081029 & $-0,042242(0,2076)$ & $0,019081(0,9381)$ \\
ETA & $1,74625(0,0000)^{* * *}$ & $(0,0066)^{* * *}$ & 0,00794 & 0,036445 \\
Adj. R-Square & 0,24318 & 0,024663 & 0
\end{tabular}

Note: TQ: Tobin's Q, ROAA: Return on Average Asset, ROAE: Return on Average Equity, NIM: Net Interest Margin, GEN: Gender diversity, NAT: Citizenship diversity, EDU: Educational background, LnTA: Ln of Total Assets, ETA: Percentage of Total Equity to Total Asset. The values not in parentheses are coefficients and in parentheses are significance. Significance at $10 \%, 5 \%$, and $1 \%$ is marked with *, **, ***.

Re-estimation using Panel Data Regression with Fixed and Random Effects methods is done to determine the effect of heterogeneity between companies. Meanwhile, the selection of the effects of each model is based on the Chow Test and Hausman Test in Table 5. The results in table 5 explain the effects selected in the estimation model and the coefficients and significance of each independent variable. By incorporating heterogeneity of each company, it can be seen that there is now a significant influence given by each of the independent variables that describe the diversity, particularly on the model TQ and NIM. By incorporating the effect of the difference between the company, the ability of the model estimation also increases, seen from the Adj. The R-Square is higher than the Pooled OLS model (except for the ROAA model). 
Table 5. Chow Test and Hausman Test Results

\begin{tabular}{ccc}
\hline Regression Model & Model Selection Test & Significance \\
\hline Model 1 (TQ) & Chow Test & 0 \\
& Hausmann Test & 0,167 \\
Model 2 (NIM) & Chow Test & 0 \\
& Hausmann Test & 0,0011 \\
Model 3 (ROAA) & Chow Test & 0 \\
& Hausmann Test & 0,8581 \\
Model 4 (ROAE) & Chow Test & 0 \\
& Hausmann Test & 0,7152 \\
\hline
\end{tabular}

Table 6. Estimation Results Using Panel Data with Fixed and Random Effects

\begin{tabular}{|c|c|c|c|c|}
\hline Variable & Model 1 (TQ) & Model 2 (NIM) & Model 3 (ROAA) & Model 4 (ROAE) \\
\hline $\begin{array}{c}\text { Cross-Section } \\
\text { Effect }\end{array}$ & Random & Fixed & Random & Random \\
\hline Constant & $0,754485^{* * *}$ & $0,056313^{* * *}$ & 0,008794 & $-0,047722$ \\
\hline GEN & $0,022684(0,8594)$ & $\begin{array}{l}-0,023272 \\
(0,0103)^{* *}\end{array}$ & $0,000577(0,9646)$ & $0,070829(0,4437)$ \\
\hline NAT & $\begin{array}{l}-0,352985 \\
(0,0534)^{*}\end{array}$ & $\begin{array}{l}-0,041531 \\
(0,0003)^{* * *}\end{array}$ & $0,016966(0,3589)$ & $0,029780(0,8232)$ \\
\hline EDU & $-0,050160(0,4189)$ & $\begin{array}{c}0,008452 \\
(0,0016)^{* * *}\end{array}$ & $0,004455(0,4842)$ & $0,011516(0,8181)$ \\
\hline LnTA & $\begin{array}{c}0,366806 \\
(0,0014)^{* * *}\end{array}$ & $-0,002063(0,6733)$ & $0,019227(0,0974)^{*}$ & $0,256771(0,0053)^{\star * *}$ \\
\hline ETA & $\begin{array}{c}2,427906 \\
(0,0000)^{* * *}\end{array}$ & $\begin{array}{l}-0,038504 \\
(0,0348)^{\star *}\end{array}$ & $-0,064819(0,0752)^{*}$ & $0,199019(0,4668)$ \\
\hline Adj. R-Square & 0,325453 & 0,887305 & 0,007032 & 0,042210 \\
\hline
\end{tabular}

Note: TQ: Tobin's Q, ROAA: Return on Average Asset, ROAE: Return on Average Equity, NIM: Net Interest Margin, GEN: Gender diversity, NAT: Citizenship diversity, EDU: Educational background, LnTA: Ln of Total Assets, ETA: Percentage of Total Equity to Total Asset. The values not in parentheses are coefficients and in parentheses are significance. Significance at $10 \%, 5 \%$, and $1 \%$ is marked with *,**, ***.

In table 6, The GEN variable that represents gender diversity, Model 1 (TQ), Model 3 (ROAA), and Model 4 (ROAE) shows a positive but insignificant coefficient. Model 2 (NIM) shows a negative and significant coefficient indicating that the presence of women in the board of directors' composition reduces the bank's financial performance.

In Model 1 (TQ), the NAT variable negatively affects directors who have foreign citizenship reduces the bank's financial performance. This is also in line with Model 2 (NIM) results, which also negatively affects. Model 3 (ROAA) and Model 4 (ROAE) have a positive coefficient on the NAT variable, but it is not significant.

In Model 2 (NIM), the EDU variable has a positive effect, indicating that directors with educational backgrounds related to the business sector positively influence the bank's financial performance. It is also in line with Model 3 (ROAA) and Model 4 (ROAE) in the 
direction of the coefficient, but the EDU variable is not significant in both models. Model 1 (TQ) contrasts with Model 2 by having a negative but insignificant coefficient.

The LnTA control variable, which shows the size of the bank in Model 1 (TQ), Model 3 (ROAA), and Model 4 (ROAE) shows a positive effect on financial performance, with Model 2 (NIM) having contradictory but insignificant results. The ETA variable that shows the bank's capital structure shows that Model 1 (TQ) positively affects financial performance, and Model 4 (ROAE) also shows a positive but insignificant coefficient. Model 2 (NIM) and Model 3 (ROAA) show a negative effect on financial performance.

Table 7. Panel Data Stationarity Test Results

\begin{tabular}{|c|c|c|c|c|c|c|c|}
\hline \multirow{2}{*}{$\begin{array}{c}\begin{array}{c}\text { Stationary } \\
\text { Test }\end{array} \\
\text { Variable }\end{array}$} & \multicolumn{4}{|c|}{ Normal } & \multicolumn{3}{|c|}{ 1st difference } \\
\hline & $\begin{array}{c}\text { Levin, } \\
\text { Lin\& Chu }\end{array}$ & $\begin{array}{c}\text { Lm, } \\
\text { Pesaran } \\
\text { and Shin } \\
\text { W-stat }\end{array}$ & $\begin{array}{c}\text { ADF - } \\
\text { Fischer } \\
\text { Chi-square }\end{array}$ & $\begin{array}{c}\text { PP - } \\
\text { Fischer } \\
\text { Chi-square }\end{array}$ & $\begin{array}{c}\text { Levin, } \\
\text { Lin\& Chu }\end{array}$ & $\begin{array}{c}\text { ADF - } \\
\text { Fischer } \\
\text { Chi-square }\end{array}$ & $\begin{array}{c}\text { PP - } \\
\text { Fischer } \\
\text { Chi-square }\end{array}$ \\
\hline TQ & $\begin{array}{c}-7,44509 \\
(0,0000)^{* * *}\end{array}$ & $\begin{array}{l}-1,35050 \\
(0,0884)^{*}\end{array}$ & $\begin{array}{l}78,4441 \\
(0,4012)\end{array}$ & $\begin{array}{l}86,1487 \\
(0,1997)\end{array}$ & $\begin{array}{c}-46,9416 \\
(0,0000)^{\star * *}\end{array}$ & $\begin{array}{c}201,610 \\
(0,0000)^{* * *}\end{array}$ & $\begin{array}{c}221,390 \\
(0,0000)^{* * *}\end{array}$ \\
\hline NIM & $\begin{array}{c}-3,86982 \\
(0,0001)^{* * *}\end{array}$ & $\begin{array}{l}1,04652 \\
(0,8523)\end{array}$ & $\begin{array}{l}53,2168 \\
(0,9675)\end{array}$ & $\begin{array}{l}51,4677 \\
(0,9786)\end{array}$ & $\begin{array}{c}-864,535 \\
(0,0000)^{* * *}\end{array}$ & $\begin{array}{c}160,678 \\
(0,0000)^{* * *}\end{array}$ & $\begin{array}{c}189,260 \\
(0,0000)^{* * *}\end{array}$ \\
\hline ROAA & $\begin{array}{c}-42,5057 \\
(0,0000)^{* * *}\end{array}$ & $\begin{array}{c}-10,6291 \\
(0,0000)^{* * *}\end{array}$ & $\begin{array}{c}139,123 \\
(0,0000)^{\star * *}\end{array}$ & $\begin{array}{c}148,775 \\
(0,0000)^{\star * *}\end{array}$ & $\begin{array}{c}-24,8719 \\
(0,0000)^{* * *}\end{array}$ & $\begin{array}{c}152,583 \\
(0,0000)^{* * *}\end{array}$ & $\begin{array}{c}184,320 \\
(0,0000)^{* * *}\end{array}$ \\
\hline ROAE & $\begin{array}{c}-17,4480 \\
(0,0000)^{* * *}\end{array}$ & $\begin{array}{c}-7,22891 \\
(0,0000)^{* * *}\end{array}$ & $\begin{array}{c}146,140 \\
(0,0000)^{\star * *}\end{array}$ & $\begin{array}{c}178,889 \\
(0,0000)^{* * *}\end{array}$ & $\begin{array}{c}-21,8548 \\
(0,0000)^{\star * *}\end{array}$ & $\begin{array}{c}158,410 \\
(0,0000)^{* * *}\end{array}$ & $\begin{array}{c}200,746 \\
(0,0000)^{\star * *}\end{array}$ \\
\hline GEN & $\begin{array}{c}-10,1102 \\
(0,0000)^{* * *}\end{array}$ & $\begin{array}{c}-2,81583 \\
(0,0024)^{* * *}\end{array}$ & $\begin{array}{c}62,6776 \\
(0,0513)^{*}\end{array}$ & $\begin{array}{c}73,2747 \\
(0,0064)^{\star * *}\end{array}$ & $\begin{array}{c}-19,2607 \\
(0,0000)^{* * *}\end{array}$ & $\begin{array}{c}97,5900 \\
(0,0000)^{* * *}\end{array}$ & $\begin{array}{c}108,108 \\
(0,0000)^{* * *}\end{array}$ \\
\hline NAT & $\begin{array}{c}-232,770 \\
(0,0000)^{\star * *}\end{array}$ & $\begin{array}{c}-68,8058 \\
(0,0000)^{* * *}\end{array}$ & $\begin{array}{c}40,5790 \\
(0,0006)^{* * *}\end{array}$ & $\begin{array}{c}51,8940 \\
(0,0000)^{\star * *}\end{array}$ & $\begin{array}{c}-210,019 \\
(0,0000)^{* * *}\end{array}$ & $\begin{array}{c}45,4227 \\
(0,0004)^{* * *}\end{array}$ & $\begin{array}{c}54,7957 \\
(0,0000)^{\star * *}\end{array}$ \\
\hline EDU & $\begin{array}{c}-0,86472 \\
(0,1936)\end{array}$ & $\begin{array}{l}0,68990 \\
(0,7549)\end{array}$ & $\begin{array}{l}1,90791 \\
(0,9280)\end{array}$ & $\begin{array}{l}1,68917 \\
(0,9460)\end{array}$ & $\begin{array}{c}-3,66602 \\
(0,0001)^{* * *}\end{array}$ & $\begin{array}{l}3,94319 \\
(0,1392)\end{array}$ & $\begin{array}{l}5,52671 \\
(0,0631)\end{array}$ \\
\hline LnTA & $\begin{array}{c}-9,03859 \\
(0,0000)^{* * *}\end{array}$ & & $\begin{array}{c}127,965 \\
(0,0002)^{\star * *}\end{array}$ & $\begin{array}{c}147,629 \\
(0,0000)^{\star * *}\end{array}$ & $\begin{array}{c}-17,4827 \\
(0,0000)^{* * *}\end{array}$ & $\begin{array}{c}213,553 \\
(0,0000)^{\star \star *}\end{array}$ & $\begin{array}{c}213,907 \\
(0,0000)^{* * *}\end{array}$ \\
\hline ETA & $\begin{array}{c}-16,4663 \\
(0,0000)^{* * *}\end{array}$ & $\begin{array}{c}-5,46393 \\
(0,0000)^{\star * *}\end{array}$ & $\begin{array}{c}124,772 \\
(0,0004)^{* * *}\end{array}$ & $\begin{array}{c}157,116 \\
(0,0000)^{* * *}\end{array}$ & $\begin{array}{c}-15,0043 \\
(0,0000)^{* * *}\end{array}$ & $\begin{array}{c}175,300 \\
(0,0000)^{* * *}\end{array}$ & $\begin{array}{c}208,771 \\
(0,0000)^{* * *}\end{array}$ \\
\hline
\end{tabular}

Note: TQ: Tobin's Q, ROAA: Return on Average Asset, ROAE: Return on Average Equity, NIM: Net Interest Margin, GEN: Gender diversity, NAT: Citizenship diversity, EDU: Educational background, LnTA: Ln of Total Assets, ETA: Percentage of Total Equity to Total Asset. The values not in parentheses are coefficients and in parentheses are significance. Significance at $10 \%, 5 \%$, and $1 \%$ is marked with $*, * * * *$.

The study conducted a panel data stationarity test in Table 7 above using the Levin, Lin, \& Chu, Lm, Pesaran, and Shin W-stat, Augmented Dickey-Fuller - Fischer Chi-square, and Phillips-Perron - Fischer Chi-Square methods. The unit root in panel data is detected by not rejecting the null hypothesis of the stationarity testing method above. Some variables have a unit root. When differencing is not performed on panel data, it is indicated by a variable that does not reject the null hypothesis. The variable does not have a unit root. When differencing has been carried out it means that the panel data is stationary to be used in this study. 
Table 8. Variance Inflation Factor (VIF) Results

\begin{tabular}{ccccccccc}
$\begin{array}{c}\text { Variance } \\
\text { Inflation } \\
\text { Factor }\end{array}$ & \multicolumn{2}{c}{ Model 1 (TQ) } & \multicolumn{2}{c}{ Model 2 (NIM) } & Model 3 (ROAA) & Model 4 (ROAE) \\
\hline Variable & VIF & $1 /$ VIF & VIF & 1/VIF & VIF & $1 /$ VIF & VIF & $1 /$ VIF \\
GEN & 1,007968 & 0,992095 & 1,029350 & 0,971487 & 1,008512 & 0,991560 & 1,014294 & 0,985907 \\
NAT & 1,026535 & 0,974151 & 1,096772 & 0,911767 & 1,026153 & 0,974514 & 1,024068 & 0,976498 \\
EDU & 1,021541 & 0,978913 & 1,018821 & 0,981527 & 1,021782 & 0,978682 & 1,024486 & 0,976099 \\
LnTA & 1,128931 & 0,885794 & 1,207229 & 0,828343 & 1,127672 & 0,886783 & 1,117236 & 0,895066 \\
ETA & 1,113581 & 0,898004 & 1,145151 & 0,873247 & 1,113501 & 0,898068 & 1,113882 & 0,897761 \\
\hline
\end{tabular}

Note: TQ: Tobin's Q, ROAA: Return on Average Asset, ROAE: Return on Average Equity, NIM: Net Interest Margin, GEN: Gender diversity, NAT: Citizenship diversity, EDU: Educational background, LnTA: Ln of Total Assets, ETA: Percentage of Total Equity to Total Asset.

Table 8 examines the multicollinearity problem by looking at the Variance Inflation Factor and shows no issues in the four regression models. The VIF value is in the range 1 10 so that the panel data is empirically valid. There was no VIF value greater than ten and a VIF value less than one, so the results could be confirmed statistically.

Table 9. Incremental Regression Results

\begin{tabular}{|c|c|c|c|c|c|c|c|c|}
\hline \multirow[b]{2}{*}{$\begin{array}{l}\text { Incremental } \\
\text { Regression }\end{array}$} & \multicolumn{2}{|c|}{ Model 1 (TQ) } & \multicolumn{2}{|c|}{ Model 2 (NIM) } & \multicolumn{2}{|c|}{ Model 3 (ROAA) } & \multicolumn{2}{|c|}{ Model 4 (ROAE) } \\
\hline & $\begin{array}{l}\text { R-Squared } \\
\text { Value }\end{array}$ & $\begin{array}{l}\text { Change in } \\
\text { R-Squared } \\
\text { Value }\end{array}$ & $\begin{array}{c}\mathrm{R}- \\
\text { Squared } \\
\text { Value }\end{array}$ & $\begin{array}{c}\text { Change in } \\
\text { R-Squared } \\
\text { Value }\end{array}$ & $\begin{array}{c}\mathrm{R}- \\
\text { Squared } \\
\text { Value }\end{array}$ & $\begin{array}{c}\text { Change in } \\
\text { R-Squared } \\
\text { Value }\end{array}$ & $\begin{array}{c}\text { R- } \\
\text { Squared } \\
\text { Value }\end{array}$ & $\begin{array}{c}\text { Change in } \\
\text { R-Squared } \\
\text { Value }\end{array}$ \\
\hline $\begin{array}{l}\text { R-Squared } \\
\text { (Original) }\end{array}$ & 0,325453 & & 0,887305 & & 0,007032 & & 0,042210 & \\
\hline $\begin{array}{c}\text { R-Squared } \\
\text { (After removal } \\
\text { GEN) }\end{array}$ & 0,328578 & $-0,003125$ & 0,881162 & 0,006143 & 0,013700 & $-0,006668$ & 0,044729 & $-0,002519$ \\
\hline $\begin{array}{c}\text { R-Squared } \\
\text { (After removal } \\
\text { NAT) }\end{array}$ & 0,312845 & 0,012608 & 0,873240 & 0,014065 & 0,008052 & $-0,001020$ & 0,048362 & $-0,006152$ \\
\hline $\begin{array}{c}\text { R-Squared } \\
\text { (After removal } \\
\text { EDU) }\end{array}$ & 0,326703 & $-0,001250$ & 0,877291 & 0,010014 & 0,010357 & $-0,003325$ & 0,048250 & $-0,006040$ \\
\hline $\begin{array}{c}\text { R-Squared } \\
\text { (After removal } \\
\text { LnTA) }\end{array}$ & 0,265255 & 0,060198 & 0,854910 & 0,032395 & 0,003509 & 0,003523 & $\begin{array}{c}- \\
0,007503\end{array}$ & 0,049713 \\
\hline $\begin{array}{c}\text { R-Squared } \\
\text { (After removal } \\
\text { ETA) }\end{array}$ & 0,116308 & 0,209145 & 0,883541 & 0,003764 & $\begin{array}{c}- \\
0,008098\end{array}$ & $-0,001066$ & 0,045089 & $-0,002879$ \\
\hline
\end{tabular}

Note: TQ: Tobin's Q, ROAA: Return on Average Asset, ROAE: Return on Average Equity, NIM: Net Interest Margin, GEN: Gender diversity, NAT: Citizenship diversity, EDU: Educational background, LnTA: Ln of Total Assets, ETA: Percentage of Total Equity to Total Asset.

The researcher conducted a robustness test in Table 9, showing changes in the Rsquared value using the incremental regression method. The results revealed two variables, when removed, demonstrated a drastic change, namely the ETA and LnTA variables. The ETA variable reduces R-Squared Model 1 (TQ) by 0.209145, and the LnTA variable reduces 
R-Squared Model 4 (ROAE) by 0.049713. This shows that the ETA and LnTA variables significantly affect bank performance.

Table 10. Endogeneity Test Results

\begin{tabular}{ccccc}
\hline Endogeneity Test & Model 1 (TQ) & Model 2 (NIM) & $\begin{array}{c}\text { Model 3 } \\
\text { (ROAA) }\end{array}$ & Model 4 (ROAE) \\
\hline Constant & 0,732207 & 0,053582 & 0,005532 & $-0,094968$ \\
GEN & $0,094727(0,6996)$ & $-0,023611(0,0205)$ & $\begin{array}{c}0,011433 \\
(0,6442)\end{array}$ & $0,246530(0,1860)$ \\
NAT & $-0,351647(0,0568)$ & $-0,041612$ & $\begin{array}{c}0,017543 \\
(0,0003)^{* * *}\end{array}$ & $\begin{array}{c}(0,3363) \\
0,038413(0,7670)\end{array}$ \\
EDU & $-0,055040(0,3913)$ & $0,010893(0,7418)$ & $\begin{array}{c}0,003617 \\
(0,5813)\end{array}$ & $-0,003090(0,9521)$ \\
LnTA & 0,395035 & $0,003493(0,9629)$ & 0,023693 & 0,329831 \\
& $(0,0059)^{* * *}$ & $-0,1022)$ & $(0,0038)^{* * *}$ \\
ETA & 2,279516 & $-0,038536$ & $-0,087827$ & $-0,204821(0,6478)$ \\
Residuals & $(0,0001)^{* * *}$ & $(0,0355)^{* *}$ & $(0,1022)$ & \\
Adj. R-Square & $1,09 \mathrm{E}+14(0,7327)$ & $3,06 \mathrm{E}+12(0,9409)$ & $\begin{array}{c}1,66 \mathrm{E}+13 \\
(0,6090)\end{array}$ & $2,70 \mathrm{E}+14(0,2810)$ \\
\hline
\end{tabular}

Note: TQ: Tobin's Q, ROAA: Return on Average Asset, ROAE: Return on Average Equity, NIM: Net Interest Margin, GEN: Gender diversity, NAT: Citizenship diversity, EDU: Educational background, LnTA: Ln of Total Assets , ETA: Percentage of Total Equity to Total Asset. The values not in parentheses are coefficients and in parentheses are significance. Significance at $10 \%, 5 \%$, and $1 \%$ is marked with *,**,***.

Table 10 is a two-step-regression endogeneity test to check whether the model has problems based on endogenous properties. Research in the first stage uses the EDU variable as the dependent variable. It regresses with all independent variables then calculates the residual. The second stage uses the dependent variable from the bank performance meter and regresses all independent variables used in the study and residuals that have been previously calculated. The results show that the residual does not significantly explain the four dependent variables for measuring bank performance, so that the endogeneity problem does not exist in the four models.

\section{DISCUSSION}

The Effect of the President Director's Educational Background on the Bank's Performance

The results of this study indicate that the president director's educational background has a positive effect on bank performance, which means that a leader with experience in business education, management, accounting, etc., will positively influence bank performance. This is possible because leaders with educational backgrounds related to business know and make better decisions, especially in the research sample, namely banks. This study is consistent with research conducted by (King et al., 2016) that the educational background of a leader with an MBA degree is likely to achieve higher profitability compared to someone without an MBA. Research by (El Sharkawy et al., 2018) said that corporate leaders with MBA degrees would make riskier and more innovative choices to achieve superior performance in the context of risk. 
This study has inconsistent results with the research conducted by (Mahadeo et al. 2012) regarding the existence of a negative relationship between educational background and company performance and by (Gottesman and Morey, 2010), who did not find an association between academic experience and company performance. Jalbert et al. (2011) saw that a company leader without a college degree could score more profits than those with a degree. Lindorff \& Jonson (2013) said that there is no relationship between the president director and MBA degrees, business degrees, or other qualifications to the company's financial performance.

\section{Effect of Gender Diversity on Bank Performance}

The results of the study in the regression model (NIM) indicate that gender diversity has a negative effect on bank performance which means that the presence of women in the composition of the board of directors will have a negative effect on bank performance. This study contradicts research by (Campbell \& Minguez-Vera, 2008) that the quality of the supervisory role of directors can be influenced by the gender composition, which will affect the company's financial performance. Research from (Wang 2020) and (Ionascu et al., 2018) also found a positive correlation and a significant effect on the involvement of women on the board of directors.

The analysis of the sex diversity coefficient variable (GEN) in the regression model (TQ) is positive but not significant. This is consistent with research by Adam \& Ferreira (2009) that there is no effect of women's involvement as a board of directors on company performance in the United States. Research by Astuti (2017) states that the proportion of female boards of directors does not affect firm value. Analysis by Post \& Byron (2015) failed to find a positive and significant correlation to company performance for the involvement of women on the board of directors. Furthermore, Research by Fernandez-Temprano \& Tejerina-Gaite (2020) shows no evidence of the impact of gender diversity on performance.

\section{The Influence of Citizenship Diversity on Bank Performance}

The results of this study indicate that citizenship diversity has a negative effect on bank performance. This indicates that the presence of a foreign director in the composition of the board of directors will reduce the bank's performance. This is made possible by unfamiliar information regarding regulations and laws in the country where the national director resides, especially in the sample of this study, namely banks. This study is in line with research (Elsharkawy et al., 2018), highlighting that boards of directors who are foreign nationals may experience domestic barriers such as awareness of industry regulations or overall job performance. Moreover, this may make them less likely to have a positive effect on the process of decision-making. Frijns et al. (2016) also found that the board's diversity negatively affects company performance.

This study is not in line with the study by (Mazzotta et al., 2017), who found a significant positive relationship between the presence of directors with foreign citizenship and Tobin's Q and by (Estélyi \& Nisar, 2016). Moreover, in his research, it was found that boards with multiple nationalities have a positive and significant relationship with the heterogeneity of shareholders and company operations in the market. International. Rahma \& Aldi (2020) found that there are foreign members of the board of directors, indicating that globalization and the exchange of information globally and indirectly can convince foreign investors that the company has been managed professionally. 


\section{CONCLUSIONS, LIMITATIONS, AND SUGGESTIONS}

This study attempts to analyze the relationship between the gender diversity of board members, the national diversity of board members, the president director's educational background, and the financial performance of banks using bank data in Indonesia. This study measures bank performance using a market-based measure (TQ) as well as accounting-based measures (ROAA, ROAE, and NIM). This study uses a variety of econometric techniques such as OLS, and static panel data models. This study uses data from 38 banks listed on the Indonesia Stock Exchange based on 190 bank data observations during the 2015-2019 period as a sample. The research team found differences in the results obtained when using different econometric techniques on more than one performance measure, at least at the level of significance in the study of the relationship between variables.

The research team's study found that the two factors of the board of directors diversity, namely gender and nationality diversity with respect to corporate governance, have a significant negative correlation effect on bank financial performance. Meanwhile, the educational background of the president director has a significant positive correlation effect on the bank's financial performance. In this study, it can be concluded that the two diversity factors discussed, namely gender diversity in the form of women's involvement and the diversity of nationalities on the board of directors, will drastically reduce the financial performance of banks. Gender diversity in the board of directors of bank companies in Indonesia is likely to trigger much different financial decision-making and strategic bank actions. Likewise, the diversity of nationalities can lead to obstacles in decision-making and strategic bank actions because foreign directors are not familiar with the laws in force in Indonesia.

In contrast to the two factors of diversity, having a president director with a background in economics or business education has a strong influence. It is perfect for the financial performance of the bank. This case can happen because, from an economic or business background, the managing director is able to take the right steps and make better decisions for the bank.

This research can assist the regulatory authorities in Indonesia in regulating the composition of the board of directors of financial institutions, particularly banks in Indonesia. With this research, bank companies can also take appropriate policy steps in regulating the preparation and appointment of prospective members of the board of directors who will serve. Overall, this research can assist banks in Indonesia in increasing their understanding of banks regarding corporate governance mechanisms.

\section{REFERENCES}

Adam, R. B., Ferreira, D. (2009). "Women in the boardroom and their impact on governance and performance", Journal of Financial Economics, 94 (2): 291-309. https:// doi.org/10.1016/j.jfineco.2008.10.007

Adnan, M. F., Sabli, N., Rashid, M. Z. A., Hashim, A., Paino, H., \& Abdullah, A. (2016). The Impact of Educational Level of Board of Directors on Firms' Performance. In Regional Conference on Science, Technology and Social Sciences (RCSTSS 2014). https://doi.org/10.1007/978-981-10-1458-1_4 
Astuti, E. P. (2017). Pengaruh Diversitas Dewan Direksi terhadap Nilai Perusahaan pada Perusahaan Manufaktur yang Terdaftar di Bursa Efek Indonesia Periode 2008-2011. KREATIF : Jurnal Ilmiah Prodi Manajemen Universitas Pamulang, 4(2), 159-179. https:// dx.doi.org/10.32493/jk.v4i2.y2017.p\%25p

Bulog, I. (2016). The influence of top management demographic characteristics on decision making approaches. Ekonomski Vjesnik/Econviews-Review of Contemporary Business, Entrepreneurship and Economic Issues, 29(2), 393-403.

Campbell, K., \& Mínguez-Vera, A. (2008). Gender diversity in the boardroom and firm financial performance. Journal of Business Ethics, 83(3), 435-451. https://doi.org/10.1007/s10551-007-9630-y

Carter, D. A., Simkins, B. J., and Simpson, W. G. (2003). "Corporate governance, board diversity, and firm value", Financial Review, 38(1): 33-53. https:// doi.org/10.1111/1540-6288.00034

Elsharkawy, M., Paterson, A. S., \& Sherif, M. (2018). Now you see me: Diversity, CEO education, and bank performance in the UK. Investment Management and Financial Innovations, 15(1), 277-291. https:// doi.org/10.21511/imfi.15(1).2018.23

Endrawati, Hikmah. (2017). Gender Diversity in Board Of Directors and Firm Performance: Study in Indonesia Sharia banks. SIBR Conference on Interdisciplinary Business and Economics Research.

Estélyi, K. S., \& Nisar, T. M. (2016). Diverse boards: Why do firms get foreign nationals on their boards? Journal of Corporate Finance, 39, 174-192. https:// doi.org/10.1016/j.jcorpfin.2016.02.006

Falato, A., Li, D., \& Milbourn, T. (2015). Which skills matter in the market for CEOs? Evidence from pay for CEO credentials. Management Science. https:// doi.org/10.1287/mnsc.2014.2024

Fernandez-Temprano, M., A., \& Tejerina-Gaite, F. (2020). Types of director, board diversity, and firm performance. Corporate Governance, 20 (2), 324-342. https:// doi.org/10.1108/CG-03-2019-0096

Frijns, B., Dodd, O., \& Cimerova, H. (2016). The impact of cultural diversity in corporate boards on firm performance. Journal of Corporate Finance, 41, 521-541. https:// doi.org/10.1016/j.jcorpfin.2016.07.014

García-Meca, E., García-Sánchez, I. M., \& Martínez-Ferrero, J. (2015). Board diversity and its effects on bank performance: An international analysis. Journal of Banking \& Finance, 53, 202-214. https:/ / doi.org/10.1016/j.jbankfin.2014.12.002

García Martín, C. J., \& Herrero, B. (2018). Boards of directors: composition and effects on the performance of the firm. Economic Research-Ekonomska Istrazivanja . https:// doi.org/10.1080/1331677X.2018.1436454 
Geiger, S. W., \& Marlin, D. (2012). The Relationship Between Organizational / Board Characteristics and the Extent of Female Representation on Corporate Boards Author ( s ): Scott W. Geiger and Dan Marlin Published by : Pittsburg State University Stable URL: http:/ /www.jstor.org/stable/43. Journal of Managerial Issues, 24(2), 157-172.

Gottesman, A. a, \& Morey, M. R. (2010). CEO educational background and firm financial performance. Journal of Applied Finance.

Goyal, R., Kakabadse, N., \& Kakabadse, A. (2019). Improving corporate governance with functional diversity on FTSE 350 boards: directors' perspective. Journal of Capital Markets Studies. https:/ / doi.org/10.1108/jcms-09-2019-0044

Ionascu, M., Ionascu, I., Sacarin, M., \& Minu, M. (2018). Women on boards and financial performance: Evidence from a European emerging market. Sustainability (Switzerland). https:// doi.org/10.3390/su10051644

Jalbert, T., Rao, R., \& Jalbert, M. (2011). Does School Matter? An Empirical Analysis Of CEO Education, Compensation, And Firm Performance. International Business \& Economics Research Journal (IBER). https:/ / doi.org/10.19030/iber.v1i1.3882

Jamali, D., Safieddine. M., and Daouk. A. (2007). "Corporate governance and women: an empirical study of top and middle women managers in the Lebanese banking sector", Corporate Governance: The International Journal of Business in Society, 7 (5): 574 585. https://doi.org/10.1108/14720700710827167

King, T., Srivastav, A., \& Williams, J. (2016). What's in an education? Implications of CEO education for bank performance. Journal of Corporate Finance. https:// doi.org/10.1016/j.jcorpfin.2016.01.003

Lindorff, M, \& Jonson, E. P. (2013). CEO business education and firm financial performance: a case for humility rather than hubris, Education + Training, 55, (4): 461-477. https:// doi.org/10.1108/00400911311326072

Mahadeo, J., Soobaroyen, T., and Hanuman V. O. (2012). "Board Composition and Financial Performance: Uncovering the Effects of Diversity in an Emerging Economy", Journal of Business Ethics, 105 (3): 375-388. https:/ / doi.org/10.1007/s10551-011-0973-z

Mazzotta, R., Bronzetti, G., \& Baldini, M. A. (2017). Does board diversity affect firm performance? Evidence from the Italian financial sector. International Journal of Business Governance and Ethics, 12(1), 65-89. https:// doi.org/10.1504/IJBGE.2017.085244

Montiel Campos, H., Solé Parellada, F., Aguilar Valenzuela, F. A., \& Magos Rubio, A. (2015). Strategic Decision-Making Speed in New Technology Based Firms. Review of Administration and Innovation - RAI. https://doi.org/10.11606/rai.v12i2.100336

Papadimitri, P., Pasiouras, F., Tasiou, M., \& Ventouri, A. (2020). The effects of board of directors' education on firms' credit ratings. Journal of Business Research, 116(462), 294-313. https:// doi.org/10.1016/j.jbusres.2020.04.059 
Pechersky, A. (2016). Diversity in Board of Directors: Review of Diversity as a Factor to Enhance Board Performance. Studia Commercialia Bratislavensia. https:// doi.org/10.1515/stcb-2016-0009

Petricevic, O., \& Teece, D. J. (2019). The structural reshaping of globalization: Implications for strategic sectors, profiting from innovation, and the multinational enterprise. Journal of International Business Studies. https://doi.org/10.1057/s41267-01900269-x

Post, C., \& Byron, K. (2015). Women on boards and firm financial performance: A metaanalysis. Academy of Management Journal. https://doi.org/10.5465/amj.2013.0319

Rahma, A. A., \& Aldi, F. (2020). The Importance of Commissioners Board Diversity in CSR Disclosures. International Journal of Economics Development Research (IJEDR), 1(2), 136-149. https:// doi.org/10.37385/ijedr.v1i2.66

Reguera-Alvarado, N., de Fuentes, P., \& Laffarga, J. (2017). Does Board Gender Diversity Influence Financial Performance? Evidence from Spain. Journal of Business Ethics. https:/ / doi.org/10.1007/s10551-015-2735-9

Saputra, W. (2019). PENGARUH DIVERSITAS DEWAN DIREKSI TERHADAP NILAI PERUSAHAAN. Jurnal Riset Manajemen Dan Bisnis (JRMB) Fakultas Ekonomi UNIAT, $4(3), \quad 503 \quad-510 . \quad$ Retrieved from https://jrmb.ejournalfeuniat.net/index.php/JRMB/article/view/294

Sarhan, A. A., Ntim, C. G., \& Al-Najjar, B. (2019). Board diversity, corporate governance, corporate performance, and executive pay. International Journal of Finance and Economics. https://doi.org/10.1002/ijfe.1690

Tarus, D. K., \& Aime, F. (2014). Board demographic diversity, Firm performance and strategic change a test of moderation. Management Research Review. https:/ / doi.org/10.1108/MRR-03-2013-0056

Upadhyay, A., \& Zeng, H. (2014). Gender and ethnic diversity on boards and corporate information environment. Journal of Business Research. https:// doi.org/10.1016/j.jbusres.2014.03.005

Wang, Y. H. (2020). Does board gender diversity bring better financial and governance performances? An empirical investigation of cases in Taiwan. Sustainability (Switzerland). https:/ / doi.org/10.3390/SU12083205 